1995

\title{
Embryos Created for Research Purposes
}

Dena S. Davis

Cleveland State University, d.davis@csuohio.edu

Follow this and additional works at: https://engagedscholarship.csuohio.edu/fac_articles

Part of the Bioethics and Medical Ethics Commons

How does access to this work benefit you? Let us know!

Original Citation

Dena S. Davis, Embryos Created for Research Purposes, 5 Kennedy Institute of Ethics Journal 343 (December 1995)

This Article is brought to you for free and open access by the Faculty Scholarship at EngagedScholarship@CSU. It has been accepted for inclusion in Law Faculty Articles and Essays by an authorized administrator of EngagedScholarship@CSU. For more information, please contact research.services@law.csuohio.edu. 


\section{Embryos Created for Research Purposes}

ABSTRACT. The creation of embryos for research use has drawn a great deal of criticism. It is difficult to defend an ethical distinction between what one can do to "spare" embryos and what one can do to "research" embryos. The strongest ground on which to argue against the creation of embryos for research is a symbolic one, having to do with respect for human life. Ronald Dworkin's work in Life's Dominion on the symbolic meaning of the abortion debate throws a helpful light on this dispute. By understanding the basic question to be, Does the creation of research embryos weaken or insult our communal respect for the sanctity of human life in some way that in vitro fertilization (IVF) or the experimental use of "spare" embryos does not?, the debate can move in a more constructive direction.

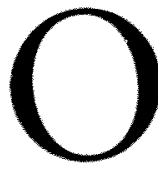

$N$ SEPTEMBER 27, 1994, the National Institutes of Health (NIH) received the Report of the Human Embryo Research Panel, a group of outside experts who had been given the challenge of advising the Institutes on which, if any, areas of research with human embryos should be considered acceptable for federal funding. On December 2, the NIH Director's Advisory Committee accepted virtually the entire report. The Report still has a long way to go before its recommendations turn into formal NIH guidelines, if they ever do, but one segment of the Panel's work already has drawn fire: the question of whether it is ever acceptable to create embryos solely for the purpose of research.

The Washington Post editorial that did the most to bring the Panel's work to the attention of the public focused almost exclusively on this issue of the creation of research embryos, calling it "unconscionable" (Embryos: Drawing the Line 1994). The responses by panel members Ronald M. Green (1994b) and R. Alta Charo (1994), as well as other ethicists, such as John Fletcher and Maria Bustillo (1994), all picked up the Post's challenge, as if this issue were at the core of the Report. 
Even within the Panel, the creation of embryos expressly for research was the most troubling issue that members had to face (Report 1994). In a panel of 19 members wrestling with a number of very difficult and potentially divisive questions, there were only three individual statements: two of them concerned this issue. Finally, despite the Panel's virtually unanimous recommendation that this type of research be funded (under carefully restricted conditions), President Clinton lost no time in announcing that he would never approve of the use of federal funds to create human embryos solely for research (Leary 1994).

In the first part of this essay, I will show the difficulties in defending a rational ethical distinction between what one can do to "spare" embryos-i.e., those left over from attempts at assisted reproductionand what one can do to embryos created for the sole purpose of research. Objections to research on any embryo (whatever its provenance) fall into a number of categories, described below. In each category, it makes no difference ethically whether the embryo was obtained as a "spare" or was created for the purpose of research. If we cannot make ethical distinctions between the use of embryos of these two different provenances, the only ground on which to argue against the creation of embryos for research purposes is, as John Robertson (1995) has pointed out, a symbolic one. In keeping with this observation, I suggest in the second part of the article that Ronald Dworkin's recent work on the symbolic meaning of our disputes over abortion and euthanasia can throw a helpful light on the current dispute over embryos created for research.

\section{OBJECTIONS TO RESEARCH WITH EMBRYOS}

1. Objections stemming from the belief that morally protectable human life-life that is ethically indistinguishable from you and me-begins when the sperm penetrates the egg-i.e., at conception. To this way of thinking, embryos command the same protection as any other human beings unable to give their own informed consent.

The archetypical example of this belief can be found in the 1995 Papal Encyclical, The Gospel of Life (Evangelium Vitae), and the 1987 Instruction on Respect for Human Life in its Origin and on the Dignity of Procreation (Donum Vitae). As the Pope says:

the use of human embryos or fetuses as an object of experimentation constitutes a crime against their dignity as human beings who have a right to 
the same respect owed to a child once born, just as to every person. (John Paul II 1995, p. 102)

The Church makes clear its belief that "personal human life" begins at the moment "the ovum is fertilized" ... "and therefore from that same moment his rights as a person must be recognized, among which in this first place is the inviolable right of every innocent human being to life" (John Paul II 1995, pp. 97-98).

According to this view, all research with embryos is forbidden unless it is aimed at benefitting the particular embryo involved (John Paul II 1995, pp. 102-3). Whether the embryo was created expressly for research or is a "spare" left over from some attempt at assisted reproduction is morally irrelevant. In fact, one of the many reasons that the Church condemns in vitro fertilization is the procedure's tendency to result in extra embryos, which are then discarded rather than nurtured toward life.

2. Objections that certain kinds of research are bad for society, or for certain segments of society. Arguments of this type come in different forms. The specter of eugenics, with its racist connotations and evil history, quite rightly haunts our ethical horizon. Even if we avoid the rhetorical overkill of the argument ad Hitlerum, we need look no further than our own United States to see offensive and dangerous eugenic tendencies that surface, drown, and surface again. Research on very early embryos certainly holds forth the threat or the promise of being able to diagnose, and perhaps even to mend, genetically diseased embryos. Among the research categories that the NIH Panel found acceptable was research involving preimplantation genetic diagnosis, although the Panel specifically excluded diagnosis for sex selection in the absence of sexlinked genetic diseases (Report 1994, p. 10). Although panel members speak of the suffering of families at risk of Lesch-Nyhan syndrome, in which affected children "eat their own flesh" (Hogan and Green 1995, p. 3), critics fear that parents may feel pressure, either internal or societal, to produce "perfect" babies, free of the "taint" of homosexuality (if such a gene were ever found) (Krimsky and Hubbard 1995), criminality (remember the XYY debate?), and so on. In the larger debate over genetic diagnosis and counseling, people who are themselves disabled have argued that the deliberate attempt to detect and abort fetuses who will be blind or deaf or otherwise handicapped calls into question the value 
and humanity of the disabled already among us. Further, the emphasis on the genetic endowment of disabled persons may mask the extent to which "the major problems of disability are not biological but social" (Asch 1989, p. 319).

Another issue that fits under this heading is the feminist concern that research on embryos, both in itself and as part of the larger project of "the medicalization of reproduction," holds special dangers for women. Numerous feminist writers have spoken about the pressures women face as a consequence of new reproductive technologies. Women may feel coerced into having only "perfect" babies (Rothman 1986; Spallone and Steinberg 1987). Women experiencing infertility may feel pressure to risk their health and undergo great suffering in order to become pregnant. Practices such as surrogacy and embryo donation may exploit women who are marginalized and vulnerable, who have no better way to earn money than by selling their reproductive capacities. A new phenomenon in Third World countries is a backlash by feminists against contraception itself, with groups such as FINRRAGE (Feminist International Network of Resistance to Reproductive and Genetic Engineering) arguing that high-tech modalities such as Norplant or "the pill" risk women's health and are one more imposition on women's fertility by a maledominated medical and scientific establishment.

To the extent that one accepts these feminist arguments, research on embryos fits into this constellation of concerns in a number of ways. The goals of such research include better and earlier genetic diagnosis, more successful in vitro fertilization and other forms of assisted reproduction, more effective contraceptives, and so on. Furthermore, the logistics of embryo research usually involve more risk to women than to men, because obtaining eggs involves invasive procedures and (usually) hormonal manipulation, while obtaining sperm merely requires ejaculation.

But again, these concerns are "global," by which I mean that they transcend the issue of the embryos' provenance and apply equally to "spare" and to "research" embryos. The one exception might be a "commodification" argument, where the fear is that economically vulnerable women could become "breeding farms" for ova used to create research embryos. In IVF programs, which produce "spare" embryos only as a secondary result, the consumers are primarily upper-class couples who want ova from women from the same ethnic and racial group as their own. In creating embryos for research, however, the racial background of the "donors" is irrelevant. Thus the creation of research 
embryos raises serious ethical concerns about the women who will provide the ova (Alpers and Lo 1995). The NIH Panel attempted to address this issue by recommending that "no payment be permitted for gametes or embryos used in research, other than reimbursement for reasonable actual expenses incurred in the donation process" (Report 1994, p. 66). However, wherever supply and demand operate, a healthy cynicism about the efficacy of bans on commercialization is certainly in order.

3. Objections that certain kinds of research are bad for the embryos themselves. Objections of this sort appear to be grounded in two notions. First, is the view that embryos younger than 14 days can be harmed in ways that parental oversight can ward off. (The Panel's recommendation is that no research be permitted on embryos older than 14 days, which is the time when the primitive streak usually appears. The only exception to this recommendation is for protocols designed to reliably identify the emergence of the primitive streak.) The second basis for the objection that certain research is bad for the embryos themselves presumes that a parental bond-and the requirement of parental informed consent-will afford a measure of protection to the embryos. Dr. Bernardine Healey's comments on the December 6, 1994, MacNeilLehrer Report exemplify this view. In objecting to embryos created for research, Healey talks about embryos for whom "the parental bond is broken," who are in "the custody of researchers," or are "wards of science." She speaks of embryos who are "in the custody of science solely to do science" and analogizes their situation to that of the retarded children who were deliberately exposed to hepatitis in the notorious Willowbrook experiment.

Such objections seem grounded in a misunderstanding of the nature of a less-than-14-day-old embryo, which does not survive a knowledge of the facts. Embryos at this stage-i.e., before the appearance of the primitive streak, which is the beginning of neural development-cannot possibly feel pain or experience any sort of sentience. If, however, there were still some lingering concern over the experience of the embryo itself, it would apply equally to embryos with and without "parents," that is, to both "spare" and "research" embryos. If, for the sake of argument, there were some possibility that these embryos could feel pain, then that would be sufficient reason for barring all research on embryos that was likely to cause pain, whether or not one could obtain parental consent. Just as one is not justified in causing significant pain to children who are 
research subjects-if they are not likely to benefit from it-regardless of whether their parents consent, one would not be justified in causing pain to embryos, if that were possible.

4. Objections that some kinds of research are so frivolous, or so unlikely to generate worthwhile results, that it trivializes the moral status of the embryo to allow the research to be done. One who holds such a position might object to projects that use human embryos without first exhausting the possibilities of research with animals. Or one might object to research (over and above the eugenic issues) that would result only in the ability to choose curly-haired kids over straight-haired ones. And, of course, one would object to research so shoddily conceived that the chances for success were slim. If one grants the human embryo any moral status at all-and both the NIH Panel and the British Warnock Report do so-it follows that one does not use them without good reason. But again, the same concern applies to all human embryos, no matter their provenance.

5. The Kantian objection. This concern about treating human beings as ends in themselves is articulated in the January 1995 statement by the Ramsey Colloquium-a conservative group of Jewish and Christian theologians, philosophers, and scholars-entitled "The Inhuman Use of Human Beings" (1995). Although the statement makes it clear that Colloquium members consider all human embryos to be morally protectable human life from their inception, the Colloquium targets the issue of made-for-research embryos from the very first sentence:

A panel of . . experts appointed by $[\mathrm{NIH}]$ has recommended government funding for conceiving human embryos in the laboratory for the sole purpose of using them as materials for research. ... [T] his recommendation is morally repugnant, entails grave injustice to innocent human beings, and constitutes an assault upon the foundational ideas of human dignity and rights essential to a free and decent society.

The statement goes on to say that " $[t]$ he ominously new thing in the Panel's Report is that embryonic human life should be treated simply as research material to be used and discarded-and should even be brought into being solely for that purpose." But the Colloquium's arguments against the Panel's recommendation do not even attempt to explain why there is something especially horrendous about bringing embryos into being solely for research purposes. The Colloquium makes powerful 
arguments, including slippery slope arguments and arguments about "personhood," but none of them explain why creating embryos for research is of greater moral repugnance than using spare embryos. The one hint is the Colloquium's reference to "one of the most treasured maxims of our civilization: that human beings are always to be treated as ends and never merely as means" and a later reference to "human beings who are valued only for their utility as tools serving the purposes of scientific research."

If one accepts the Colloquium's position that embryos from the point of conception are fully protectable human life, then their Kantian argument, were it more fully developed, might look at first blush like an argument that shows why there is a moral difference between research on "spare" embryos and the creation of embryos for research purposes. One could argue that "spare" embryos are created as part of a process that is aimed at the creation of a live and beloved baby, a baby who will be valued for its own sake as well as for the happiness it will bring its parents. Thus the spare embryo is the "fallout" of a process that at least begins by treating it as an end. In contrast, as NIH panel member Patricia King says in her individual statement, "The fertilization of human oocytes for research purposes is unnerving because human life is being created solely for human use" (Report 1994, Appendix A, Statement of Patricia A. King, Concurring in part and Dissenting in part, p. 97 , italics in the original). As John Robertson (1995, p. 38) has pointed out:

Creating research embryos is perceived symbolically as a sign of the willingness to treat human life as an instrument solely to the ends of others, without due regard for its inherent sanctity. Drawing the line at creating embryos for research ... is a powerful way of reaffirming a commitment to the value of human life at the same time that spare embryos are used to increase scientific knowledge.

Nevertheless, the Colloquium's argument is not easy to sustain in light of the typical IVF narrative: a woman is made to hyperovulate, some eight or ten ova are fertilized, and perhaps half of the resulting embryos are transferred to the womb; if a pregnancy is achieved, those embryos are often "selectively reduced" to twins; and, meanwhile, the remaining embryos are frozen in case the couple needs to try again. If unused, the "spare" embryos are eventually destroyed or donated to research. (If the embryos were really being treated as ends in themselves, it would make 
more sense to donate them to other infertile people, but this is something most couples are loathe to do.) A scenario in which the goal of a born child almost always depends upon the destruction of a number of embryos along the way is hardly one in which each embryo is treated as an end in itself. But the argument fails in any case. The Kantian maxim applies only to human beings. If embryos are fully human beings, all nontherapeutic research is out of bounds no matter the embryos' provenance. If they are not fully human beings, then the maxim does not apply.

In sum, none of the arguments most commonly used against embryo research can support the distinction between what one can do to spare embryos and what one can do to embryos made for research. In terms of how embryos may ethically be used, it appears to make no ethical difference where the embryos come from. Why, then, is this issue arousing so much passion?

\section{RESPECT FOR THE SANCTITY OF HUMAN LIFE}

One way of approaching this question is to adopt and adapt the approach that Ronald Dworkin applies to abortion in his 1993 work, Life's Dominion. Dworkin argues that we are mistaken in our assumption that the abortion debate is primarily about the fetus's "right to life" in the same sense that a born human being has a right to life. Dworkin claims that very few people, even among the most passionate pro-life supporters, truly believe in the full humanhood of the early fetus. If they did, they would never allow abortion in cases of rape, for example, something most pro-life activists are prepared to countenance. Instead, "the disagreement that actually divides people is a markedly less polar disagreement about how best to respect a fundamental idea we almost all share in some form: that individual human life is sacred" (Dworkin 1993, p. 13). In other words, how can we, as individuals and as members of democratically constituted communities, nourish and pay respect to the idea of the sanctity of human life? Dworkin believes that if we can get people to see that this is the ground on which we are disputing, we can more easily find compromise (as well as be more tolerant of conflicting views).

I believe that Dworkin's perspective provides valuable insights into the present conflict over made-for-research human embryos. There does not appear to be a rational argument for the claim that made-for-research 
embryos are more vulnerable, more fully human, or in any other way more in need of protection than "spare" embryos. Nor can the argument be that creating human life is itself a wrong. The latter argument proves too much: It would argue against all use of in vitro fertilization, but outside of the Roman Catholic Church, most of the objections to research embryos do not come from people who are against IVF per se. The salient, though unstated, argument against made-for-research embryos seems to be that the creation of human life for the sole purpose of manipulating and then destroying it weakens or insults our communal respect for the sanctity of human life in some way that IVF itself, or the experimental use of "spare" embryos, does not.

If we can agree that this is what the argument is about, we may at least stop arguing at cross purposes. I am certainly not suggesting that adopting Dworkin's path is an easy route to closure on the debate over creating embryos for research. For one thing, Dworkin's argument about abortion will not carry us all the way. His argument rests on two very important claims: first, that forcing someone to continue a pregnancy she would otherwise terminate implicates "absolutely crucial" values of freedom and noncoercion; and second, that the abortion decision is one that each person, on the grounds of religious freedom, must make for her- or himself. Neither of these claims are as robustly present in the debate over embryo research, which involves the use of federal funds in a communal-i.e., national-effort to press forward with certain avenues of research. An argument based on individual liberty and on each person's right to define the sacred for her- or himself will not be helpful in this context. We must take Dworkin's insights into the nature of the argument and navigate for ourselves from there. Let me just sketch out some of the factors we might consider if we took that tack.

1. We could begin by looking at the hoped-for gains to be achieved by permitting made-for-research embryos. Are the goals trivial? Or are they so inherently entwined with the core of human suffering and happiness that the use of research embryos in an attempt to meet them exhibits a moral seriousness that points to a respect for the sanctity of human life? According to the NIH panelists, such goals include overcoming certain kinds of infertility, learning more about bone marrow transplantation, developing more effective contraceptives, protecting women from risks associated with hormonal manipulation, and so on (Report 1994, pp. 53-57; Hogan and Green 1995, p. 2). 
According to Charo (1995, p. 24):

Because pregnancy and reproductive disorders cause over half the deaths among women ages $15-50$ in some countries, and with the risk of death from pregnancy almost 1 in 5 in Africa, access to adequate contraception is a matter of human rights as much as public health.

If Charo is right, and if made-for-research embryos are indeed a crucial desideratum for research into alternative modes of contraception, then the debate over research embryos can be recast into the following form: Do we, as a community, endanger the sanctity of human life most severely by creating embryos purely for research or by slowing the pace at which we address the plight of human beings whose human rights are yet to be fully realized? The members of the Ramsey Colloquium would side with the former, and Charo and other panel members with the latter. Thus, the debate is not resolved, but it seems to be recast in less intransigent terms. It at least becomes possible for the two sides to have a productive conversation on why the dangers of one outweigh those of the other, and how a compromise position might be realized.

2. Are the restrictions placed on the use of research embryos stringent enough to reflect a respect for these entities that betokens an expression of respect for the sanctity of human life? Another way of asking the question might be: Are the restrictions onerous? Do they make scientific work less convenient? Do they really restrict scientists?

The NIH Panel has allowed the use of research embryos under two conditions: first for research that "by its very nature cannot otherwise be validly conducted" (primarily research on the fertilization process itself), and second for research that requires made-for-research embryos in order to validate a study "that is potentially of outstanding scientific and therapeutic value." Most importantly, embryos cannot be generated solely to alleviate a scarcity of embryos available for research.

The Panel recommends other restrictions that apply to the use of all embryos, "spare" or "research." I have already alluded to the 14-day restriction on embryo research and to the ban on the purchase or sale of gametes or embryos. Further restrictions include the requirements that the research goals cannot be accomplished using animals or unfertilized gametes and that the number of embryos used for the research must be kept to the minimum.

Do these restrictions, which are more stringent than would be required for, for example, animal embryos or unfertilized human 
gametes, betoken a moral seriousness that is an appropriate reflection of the "respect" that the preimplantation embryo commands as "a form of potential human life?" (Green 1994a, p. 351). If so, is that moral seriousness sufficient to reassure us that the use of research embryos does not violate our sense of respect for the sanctity of human life?

I do not mean these to be rhetorical questions. Many people would argue that the current obsession with infertility is misplaced, and that our energies would be better spent in creating more varied opportunities for women and in facilitating adoption-e.g., transracial adoption. We might also ask if many of the desired goals can be reached by other means, albeit more slowly. And a healthy skepticism about scientists' enthusiasm for their own research projects is always in order.

Thus, the cognitive reorientation that I have adapted from Dworkin does not provide us with easy answers. But it might help to put the debate in more rational terms, to allow each side to understand better what the other is arguing about, and finally to discover some resolutions.

The author is grateful for the financial support of the Cleveland-Marshall Fund while she was writing this article.

\section{REFERENCES}

Alpers, Ann, and Lo, Bernard. 1995. Commodification and Commercialization in Human Embryo Research. Stanford Law and Policy Réview 6: 39-46. Asch, Adrienne. 1989. Can Aborting "Imperfect" Children Be Immoral? In Ethical Issues in Modern Medicine, 3d ed., ed. John Arras and Nancy Rhoden, pp. 317-21. Mountain View, CA: Mayfield Publishing Company. Charo, R. Alta. 1994. Embryo Calculus [Letter to the Editor]. Washington Post (8 October): A18.

- 1995. The Hunting of the Snark: The Moral Status of Embryos, Rightto-Lifers, and Third World Women. Stanford Law and Policy Review 6: 11-38.

Dworkin, Ronald. 1993. Life's Dominion: An Argument About Abortion, Euthanasia, and Individual Freedom. New York: Alfred A. Knopf.

Embryos: Drawing the Line. 1994. Washington Post (2 October): C6.

Fletcher, John C., and Bustillo, Maria. 1994. Embryos for Research [Letter to the Editor]. Washington Post (31 October): A22.

Green, Ronald M. 1994a. At the Vortex of Controversy: Developing Guidelines 
for Human Embryo Research. Kennedy Institute of Ethics Journal 4: 345-56. - 1994b. The Ethics of Embryo Research [Editorial]. Washington Post (18 October): A17.

Hogan, Brigid L. M., and Green, Ronald M. 1995. Embryo Research Revisited. Hastings Center Report 25 (3): 2-6.

John Paul II. 1995. Encyclical Letter, Evangelium Vitae. Boston: Pauline Books and Media.

Krimsky, Sheldon, and Hubbard, Ruth. 1995. The Business of Research. Hastings Center Report 25 (1): 42-43.

Leary, W. E. 1994. Clinton Rules Out Federal Money for Research on Human Embryos Created for the Purpose. New York Times (3 December).

Report of the Human Embryo Research Panel. 1994. Bethesda, MD: National Institutes of Health.

Robertson, John. 1995. Symbolic Issues in Embryo Research. Hastings Center Report 25 (1): 37-38.

Rothman, Barbara Katz. 1986. The Tentative Pregnancy. New York: Viking Press.

Spallone, Patricia, and Steinberg, Deborah Lynn, eds. 1987. Made to Order. Oxford: Pergamon Press.

The Inhuman Use of Human Beings: A Statement by the Ramsey Colloquium. 1995. First Things (January): 17-21. 